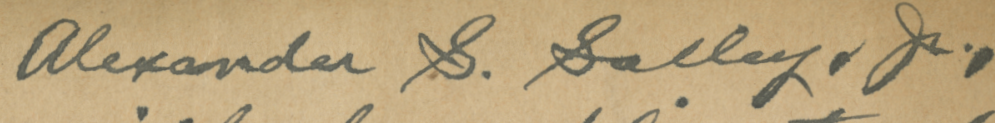

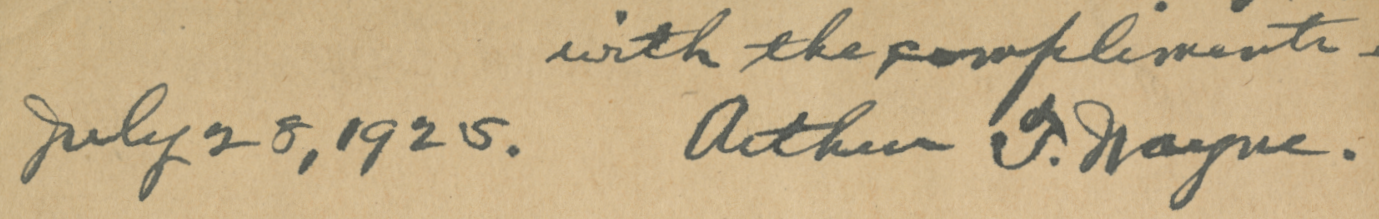

[From 'The AUk,' Vol. XXV, No. 1, January, 1908.]

THE BREEDING SEASON OF THE AMERICAN BARN OWL (STRIX PRATINCOLA) IN SOUTH CAROLINA.

BY ARTHUR T. WAYNE. 


\section{THE BREEDING SEASON OF THE AMERICAN BARN OWL (STRIX PRATINCOLA) IN SOUTH CAROLINA.}

BY ARTHUR T. WAYNE.

IN Audubon's 'Ornithological Biography,' Vol. II, pp. 404405, he states the following concerning the breeding of this species:

"Having arrived at Charleston, South Carolina, in October, 1833, as soon as my family and myself were settled in the house of my friend the Reverend John Bachman, I received information that a pair of owls (of the present species) had a nest in the upper story of an abandoned sugar-house in the city, when I immediately proceeded to the place, accompanied by Dr. Samuel Wilson and William Kunhardt, Esq. We ascended cautiously to the place, I having pulled off my boots to prevent noise. When we reached it, I found a sort of large garret filled with sugar-moulds, and lighted by several windows, one of which had two panes broken. I at once discovered the spot where the owls were by the hissing sounds of the young ones, and approached slowly and cautiously 
towards them, until within a few feet, when the parent bird seeing me, flew quickly towards the window, touched the frame of the broken panes, and glided silently through the aperture. I could not even afterwards observe the course of its flight. The young were three in number, and covered with down of a rich cream color. They raised themselves on their legs, appeared to swell, and emitted a constant hissing sound, somewhat resembling that of a large snake when angry. They continued thus without altering their position, during the whole of our stay, which lasted about twenty minutes. They were on a scattered parcel of bits of straw, and surrounded by a bank made of their ejected pellets. Very few marks of their excrements were on the floor, and they were beautifully clean. A Cotton Rat, newly caught, and still entire, lay beside them, and must have been brought from a distance of several miles, that animal abounding in the rice-fields, none of which, I believe, are nearer than three or four miles. After making some arrangements with the Negro man who kept the house, we returned home. The eggs from which these young owls had been hatched must have been laid six weeks before this date, or about the 15 th of September.

"On the 25th of November they had grown much in size, but none of the feathers had yet made their appearance, excepting the primaries, which were now about an inch long, thick, full of blood, and so tender that the least pressure of the fingers might have burst them. As the young grow more and more, the parents feed and attend to them less frequently than when very small, coming to them in the night only with food. This proves the caution of these birds in avoiding danger, and the faculty which the young possess of supporting abstinence in this middle state of their growth.

"On the 7th of December I visited the Owls in company with my friend John Bachman. We found them much grown; indeed, their primaries were well out; but their back and breast, and all their lower parts, were still thickly covered with down.

"On the 6th of January I again saw them, but one of the young was dead, although in good condition. I was surprised that their food still continued to be composed entirely of small quadrupeds, and principally of the rat mentioned above. 
"My last visit to them was on the 18th of January. The two younger ones were now, to all appearance, full grown, but were yet unable to fly. A few tufts of down still remained attached to the feathers in scattered parts of the body. I took them home. One was killed, and the skin preserved.

"Now, these facts are the more interesting, that none of the numerous European authors with whom I am acquainted, have said a single word respecting the time of breeding of this species, but appear to be more intent on producing long lists of synonyms than on presenting the useful materials from which the student of nature can draw inferences. I shall therefore leave to them to say whether our species is, or is not, the same as the one found in the churches and ruins of Europe. Should it prove to be the same species, and if the European bird breeds, as I suspect it does, at so different a period of the year, the American Owl will form a kind of mystery in the operations of nature, as they differ not only from those of the bird in question, but of all other Owls with which I am acquainted."

Although I have been endeavoring to procure the eggs of this species for more than twenty years in order to establish the normal season in which it breeds, information has only recently been obtained. A pair of these Owls has been breeding for many years in an old mill on the plantation of Mr. J. St. Clair White, near the banks of the Cooper River. Mrs. White, the wife of the owner of the plantation, in answering a communication relative to the eggs of this bird, wrote under date of January 3, 1906, as follows: "Knowing quite as much about the Owls as he [Mr. White] does, through the children, who have always been interested in them, I will state that there were young there [the old mill] a month ago." I then concluded that the eggs must be laid during the month of November and requested the sons of Mr. White to keep a close watch on the building. On November 18, 1906, Mrs. White wrote: "I had to wait for Thomas [her son] to go to the barn to find out what the Owls were doing, and as is usual at this season they have a nest of young."

As Audubon does not mention in his 'Birds of America' the account of the breeding of this species witnessed by him in Charleston, and as this work was said by him to be "similar to my large 
work" (Ornithological Biography), I naturally inferred that he was not acquainted with the breeding habits of this Owl and hoped to establish a record, when it occurred to me that I had read, when a youth, in the latter work a long account of the breeding of this species and recalled the month in which the eggs were laid. A letter was sent to Mrs. White on September 17, 1907, with the request that the mill be searched for eggs. On September 19, her son, Master Thomas Porcher White, succeeded in finding six eggs. Upon the reception of the eggs I observed that they were all laid at irregular intervals of five to twelve days, as one egg contained a very large embryo, another about one half incubated, a third had a well-formed embryo, while the others were in lesser stages of development. The first egg must have been laid not later than September 5, as it undoubtedly had been incubated for at least fourteen days:

Much credit is due young White for his untiring efforts in my behalf in order that the normal season should be definitely established.

That this species should breed in South Carolina in September is indeed remarkable, for according to Davie (Nests and Eggs of North American Birds, p. 191), it breeds in southern Florida in March, while in the region of Los Angeles, California (Lat. $34^{\circ}$ ), the breeding season extends from April until the last of June.

As no mention is made of the breeding of this owl in the States of Florida and California during the autumnal months, the spring must therefore be considered the regular season in which it breeds, unless it annually rears two broods, and if such proves to be the case the birds may be autumnal breeders in those States. The reason this species breeds in September in the low coast region of South Carolina is doubtless due to the fact that the food supply, which consists of small mammals, is more abundant and more easily procured during the autumnal and early winter months than in late winter and spring.

Since the above was written I found an account of the breeding of this owl by Mr. R. W. Williams, Jr., in 'The Auk,' XIX, 1902, p. 198, wherein he states that a set comprising five eggs was found on December 12. These observations were made at Tallahassee, which is in the northwestern part of Florida and near the Georgia line. 
Mr. R. D. Hoyt of Seven Oaks, Hillsboro County, Florida, writes me under date of Oct. 19, 1907: "No, I have never taken the Barn Owl here, and September seems a queer time for them to nest in South Carolina. This owl is very plentiful in the Cape Sable region, Florida. Two years ago I saw as many as eight or ten at a time flying over the marshes just at dusk, and it would be interesting to know when they breed in that country, as there is no timber to speak of, and in the daytime the owls roost in the grass, the same as Short-eared [Asio accipitrinus]."

I am indebted to my friend Mr. Herbert Ravenel Sass for transcribing Audubon's account in his 'Ornithological Biography.' 